\title{
Digitalization of transport services in modern Russia
}

\author{
Arsen Yarakhmedovich Akhmedov ${ }^{1}$, Yulia Nikolaevna Boyarskaya, Olga Sergeevna \\ Sotskova, Olga Fedorovna Fast, and Sergey Aleksandrovich Filippov \\ Saratov State Law Academy, Department of Civil Law, Russia
}

\begin{abstract}
The purpose of the study is to establish the features of regulation of individual relations in the digital economy. The work uses a systematic approach, methods of comparison, description, interpretation; theoretical methods of formal and dialectical logic; private scientific method: comparative legal. The result of the study was the postulates that such qualifying features of a carsharing agreement as the subject structure and the purpose of the conclusion allow us to conclude that it is necessary to refer it to a rental agreement, a feature of which is the use of a smart contract. However, a smart contract is not only a form of contract, but also a way of fulfilling contractual obligations. Its use gives a carsharing agreement clear advantage over a conventional rental agreement. The program code excludes the possibility of changing its content and violating the contract. Aggregators can participate in transportation relationships in different ways. In cases where the aggregator organizes transportation, forms the terms of the contract of carriage, it must be jointly and severally liable together with the carrier to the passenger. If the aggregator provides only an information service, then he must answer to the customer only for its quality. The novelty of the study lies in the proof that despite the fact that digital technologies are shaping new business strategies and changing the nature of legal relations, these relations are still not properly regulated by domestic legislation.
\end{abstract}

Keywords: digital economy, transport services, carsharing, smart contract

\section{Introduction}

Interest and its satisfaction are the engines of the development of economics and law, which leads to the emergence of new trends in economic interactions through the optimization of the cost of financial resources and time. The constantly emerging marketing strategies that are ahead of the current legislation require legal consolidation. The development of relations in the field of the digital economy is manifested, among other things, in the field of transport infrastructure, examples of which are the transportation of passengers by contacting an information intermediary (aggregator) and carsharing.

The issues of consumer protection in the context of the formation of a market for goods and services using digital technologies are of decisive importance for the development of

${ }^{1}$ Corresponding author: $\underline{\text { ahmedov.arsen@bk.ru }}$ 
the Russian economy, which directly correlates with the Strategy of the state policy of the Russian Federation in the field of consumer protection for the period up to 2030 [1].

The models of economic behavior of participants in civil turnover have been permanently undergoing a significant transformation over the past decades. The modern stage of social advancement is characterized by the fact that there has been a tendency of transition to a sharing economy, which includes the collective use of goods and services. Due to the fact that the consumption economy is still not losing ground, the number of intermediaries whose activities make life easier for citizens is increasing. At the same time, the determination of the legal status of market participants for goods and services using digital technologies is essential for the domestic economy.

\section{$2 \quad$ Methods}

The work uses a systematic approach, methods of comparison, description, interpretation; theoretical methods of formal and dialectical logic; private scientific method: comparative legal.

\section{$3 \quad$ Results}

Due to the lack of legislative regulation of the carsharing agreement, the question remains regarding its legal nature. It seems that a carsharing agreement should be qualified as a rental agreement. The main difference between a carsharing agreement and the types of a lease provided for in the legislation is the specificity of its conclusion, execution and termination, which is closely related to the use of smart contracts, which are characterized as a special form of concluding a contract and a method of its execution.

The conclusion of contracts for air transportation and road transportation on the Internet is not formalized by smart contracts. However, digital tools and programs are used by the information intermediary to establish contact between the carrier and the passenger. It seems that the main legal problems in the analysis of relations with the participation of aggregators for the provision of air transportation services arise in connection with the uncertainty of their legal status, as well as questions about the grounds and limits of contractual and tort liability of the participants in the relevant relations.

\section{Discussion}

Carsharing is a short-term rental with per-minute and other tariffs for intracity trips of numerous clients [2]. Initially, it was developed in the United States, where roundtrip carsharing, one-way free floating, one-way station-based and peer-to-peer carsharing are traditionally distinguished [3].

According to some carsharing companies, the rental norms do not apply to relations arising from a carsharing agreement (Adhesion contract). Nevertheless, many authors attribute it to rental, referring to its subject composition and the purpose of imprisonment [4]. Other authors and some companies note its similarity to the rental of vehicles (Lease of a vehicle without crew), which, in our opinion, is incorrect. First, it should be noted that, in contrast to the civil legislation of such countries of the continental system of law as Germany (Bürgerliches Gesetzbuch) [5], Spain (Codigo Civil) [6], Italy (Codice Civile) [7], France (Code civil) [8], Switzerland (Swiss Civil Code, Federal Act on the Amendment of the Swiss Civil Code) [9, 10], in Russian law, the vehicle lease agreement is singled out as an independent type of lease due to its specific subject composition, subject matter, and the 
goals of concluding the agreement, which differ significantly from those in the carsharing agreement [11].

A carsharing agreement is concluded through the use of a smart contract. A smart contract is a special form of concluding an agreement, which assumes the fullest possible account of the terms of the contract at the stage of its design and their formalization in the form of a program code without subsequent adjustment [12]. The contract is concluded remotely by registering the tenant in the corresponding application of the carsharing company. For this reason, a number of obligations arise between him and the company at the same time from license and user agreements.

At the same time, it is noted [13] that smart contracts are imperfect, primarily due to the lack of legal regulation. However, the benefits of a smart contract are obvious in case of carsharing. For example, when registering a tenant in the corresponding application, the details of his account are tied to his personal account, from which money will subsequently be debited for using the car [14]. The conclusion of such a contract completely excludes the possibility of improper performance of the contract.

A carsharing agreement is fundamentally different from a passenger and baggage carriage agreement. In the case of the conclusion of a contract for the carriage of a passenger, the use of digital technologies is also actively developing. Moreover, they are often used not by the carriers themselves, but by third parties (aggregators), whose activities have not been subject to any special regulations for a long time. The owner of the aggregator received an independent legal status with the entry into force of the Federal Law of July 29, 2018 No. 250-FZ "On Amendments to the Law of the Russian Federation "On Protection of Consumers' Rights" [15].

Currently, draft law No. 481004-7 has passed the first reading, the purpose of which is to regulate relations in the field of organizing and carrying out activities for the transportation of passenger taxis and the activities of ordering services for light taxis, which normatively enshrines the legal status of aggregators, defining them as information intermediaries, proposing to establish responsibility such an intermediary for harm caused to the passenger in the provision of services for the transportation organized by him [16].

The draft edition of Art. 34 of the Charter of motor transport and city ground-based electric transport, the carrier and the information intermediary are jointly and severally liable to the passenger. Entrepreneurs do not share this position and put forward proposals for the subsidiary liability of aggregators [16].

In our opinion, the approach proposed by the legislator is more logical, since it is the aggregators who predominantly determine the terms of the contract. The persons carrying out the carriage perform it on the conditions proposed by the aggregator based on the passenger's request. When forming the terms of the agreement, the passenger and the direct carrier are in a weaker position in relation to the aggregator, since they join most of the terms of the agreement defined by it. At the same time, the driver's qualifications, his well-being, knowledge of the route, the technical condition of the transport must also be controlled by the organizer of the transportation. The passenger perceives the carrier and the aggregator as one subject of the legal relationship.

While the contract for road transport charter in the vast majority of cases is concluded through the interaction between the passenger and the aggregator, the case is somewhat different with regular transport by other modes. In this case, digitalization is more pronounced in the air transportation sector: $37 \%$ of air passengers purchase tickets online, compared with $6.5 \%$ for other industries [17]. Over the past few years, the purchase of air tickets through various aggregators (Skyscanner, Aviasales, Kupibilet, Anywayanyday, etc.) has gained immense popularity due to the simplification of the procedure for purchasing air tickets. The owners of the aggregators are direct participants in the legal relationship for the sale of air tickets to passengers, without becoming directly participants in the transportation 
relationship. For this reason, the Federal Air Transport Agency (Rosaviatsiya) does not have information about them.

Thus, the legal status of aggregators occupies an intermediate position: the aggregator is responsible for the information provided to citizens (its inaccuracy and incompleteness), but is not responsible for the quality of the transportation service. We believe that there are no grounds for defining the owner of the aggregator and the carrier as joint and several debtors in this case, in contrast to the chartering of road transport.

At the same time, the owners of aggregators use different wording in the text of the agreement with the user of the website/platform on which the booking and purchase of tickets is carried out, aimed at limiting the liability of the performer. So, in the event of a complete or partial temporary inoperability of the booking system, as well as in the absence of access to the system in accordance with clause 2.11 of the user agreement of the Kupibilet aggregator, the owner of the aggregator does not bear any responsibility to the user, although the user is in fact deprived of the opportunity to track changes in the conditions of carriage. Since the main responsibility of the aggregator is to provide services for the placement of information, the ability to search, book, pay and purchase the booked services, the owner of the aggregator must be responsible for the proper and high-quality provision of such a service: for the serviceability of the services, the availability of the personal account on the aggregator's website, the availability of the posted information for site users [18]. In our opinion, responsibility for poor-quality provision of services within the meaning of Art. 12 of the Law "On Protection of Consumers' Rights" by the owners of aggregators should not be limited to the wording due to "technical problems" [15].

There are also the terms of user agreements, which in the context under consideration are difficult to agree with. So, in the offer of the Kupibilet aggregator [19, 20], a service fee is charged for ticket refunds, in particular in the event of a flight cancellation or a change in the schedule. In other words, the passenger is forced to pay a service fee for the service not provided/poorly provided by the carrier. In the event of a forced refusal of a passenger from carriage, the carriage charge and charges that make up the ticket price are subject to full refund to the passenger ([21], clause 227). Aggregators, as a rule, do not include a service charge in the ticket price and indicate that this is a surcharge for booking services. However, aggregators are often agents of airlines, and by law (Art. 1005, 1006 of the Civil Code of the Russian Federation) it is the carrier, and not the passenger, who is obliged to pay the agent a fee.

\section{Conclusion}

Digital technologies form new business strategies, change the nature of legal relations, directly influencing the need for the development of legal regulation. The transition to digital technology allows for proper contract execution, time savings, stability and protection, especially for the consumer.

In the legal regulation of some aspects of the activities of the owners of aggregators, at present, there are gaps in the legislation. However, the practice goes along the path of expanding the limits of liability of aggregators, which in some cases are involved as joint and several debtors if the passenger transportation service was not provided properly. It is important to note that the need to protect the "weak" side of the contract is taken into account.

\section{References}


1. Rasporyazhenie Pravitelstva RF ot 28 avgusta 2017 g. № 1837-r pri utverzhdenii Strategii gosudarstvennoi politiki Rossiiskoi Federatsii v oblasti zashchity prav potrebitelei na period do 2030 goda [Order of the Government of the Russian Federation of August 28, 2017 No. 1837-r when approving the Strategy of the state policy of the Russian Federation in the field of consumer protection for the period up to 2030], in Rossiiskaya Gazeta, 208(7374) (2017)

2. A.I. Bychkov, Developerskii biznes v Rossii. Pravovoe regulirovanie otrasli [Development business in Russia. Legal regulation of the industry] (Infotropic Media, Moscow, 2018)

3. A. Bansal, N. Chan, A. Cohen, S. Shaheen, Definitions, Industry Developments, and Early Understanding. Accessed on: July 11, 2021. [Online]. Available: http://innovativemobility.org/wp-content/uploads/2015/11/SharedMobility_WhitePaper FINAL.pdf

4. Yu.N. Boyarskaya, Lawyer, 8, 39-42 (2019). https://doi.org/10.18572/1812-3929-2019-8-39-43

5. Bürgerliches Gesetzbuch (BGB) [Civil Code (CC)]. Accessed on: July 11, 2021. [Online]. Available: http://www.gesetze-im-internet.de/bgb/inhalts_bersicht.html

6. Real Decreto de 24 de julio de 1889 por el que se publica el Código Civil [Royal Decree of 24 July 1889 publishing the Civil Code]. Accessed on: July 11, 2021. [Online]. Available: https://boe.es/buscar/doc.php?id=BOE-A-1889-4763

7. Codice Civile [Civil Code]. Accessed on: July 11, 2021. [Online]. Available: https://www.codice-civile-online.it

8. Code civil [Civil Code]. Accessed on: July 11, 2021. [Online]. Available: https://www.legifrance.gouv.fr/codes/id/LEGITEXT000006070721

9. Swiss Civil Code. Accessed on: July 11, 2021. [Online]. Available: https://www.fedlex.admin.ch/eli/cc/24/233_245_233/en

10. Federal Act on the Amendment of the Swiss Civil Code. Accessed on: July 11, 2021. [Online]. Available: https://www.fedlex.admin.ch/eli/cc/27/317_321_377/en

11. Dogovor arendy transportnogo sredstva bez ekipazha [Lease agreement for a vehicle without crew]. Accessed on: July 11, 2021. [Online]. Available: https://youdrive.today/oferta

12. N.P. Ivaschenko, A.E. Shastitko, A.A. Shpakova, J. Inst. Stud. 11, 064-083 (2019). https://doi.org/10.17835/2076-6297.2019.11.3.064-083

13. A.A. Volos, The Technology of Blockchain and Smart Contract and Their Regulation Under the Conflict of Laws of the European Union, in Advances in Economics, Business and Management Research, 2nd Int. Sci. and Pract. Conf. on Digital Economy 563 - 568 (2020). https://doi.org/10.2991/aebmr.k.201205.094

14. K.S. Danilov, Property Rel. RF, 10, 52-57 (2019)

15. Federalnyi zakon ot 29.07.2018 N 250-FZ "O vnesenii izmenenii v Zakon Rossiiskoi Federatsii "O zashchite prav potrebitelei” [Federal Law of 29.07.2018 N 250-FZ "On Amendments to the Law of the Russian Federation "On Protection of Consumers' Rights", in Collected Legislation of the Russian Federation, 31, 4839 (2018)

16. Zakonoproekt №481004-7 o gosudarstvennom regulirovanii otnoshenii v oblasti organizatsii i osushchestvleniya deyatelnosti po perevozke legkovym taksi i deyatelnosti sluzhb zakaza legkovogo taksi, vnesenii izmenenii v otdelnye zakonodatelnye akty Rossiiskoi Federatsii i priznanii utrativshimi silu otdelnykh polozhenii zakonodatelnykh aktov Rossiiskoi Federatsii [Draft Law No. 481004-7 on 
state regulation of relations in the field of organizing and carrying out activities for the transportation of passenger taxis and the activities of ordering services for passenger taxis, amending certain legislative acts of the Russian Federation and invalidating certain provisions of legislative acts of the Russian Federation]. Accessed on: July 11, 2021. [Online]. Available: https://sozd.duma.gov.ru/bill/481004-7

17. F.Yu. Baykov, E-Manag. 3(2), 70-76 (2020).

https://doi.org/10.26425/2658-3445-2020-2-70-76

18. L.V. Kuznetsova, Voprosy grazhdansko-pravovoi otvetstvennosti agregatorov elektronnoi kommertsii [Issues of civil liability of e-commerce aggregators], in M.A. Rozhkova (ed.), E-COMMERCE and interrelated areas (legal regulation), 39-65 (Statut, Moscow, 2019)

19. Dogovor prisoedineniya [Adhesion contract]. Accessed on: July 11, 2021. [Online]. Available: https://belkacar.ru/legal/contract.pdf

20. Oferta [Offer]. Accessed on: July 11, 2021. [Online]. Available: https://www.kupibilet.ru/agreement

21. Prikaz Mintransa Rossii ot 28.06.2007 N 82 (red. ot 15.09.2020) “Ob utverzhdenii Federalnykh aviatsionnykh pravil "Obshchie pravila vozdushnykh perevozok passazhirov, bagazha, gruzov i trebovaniya k obsluzhivaniyu passazhirov, gruzootpravitelei, gruzopoluchatelei" [Order of the Ministry of Transport of Russia of June 28, 2007 N 82 (revised on September 15, 2020) "On approval of the Federal Aviation Rules "General rules for the air transportation of passengers, baggage, cargo and requirements for servicing passengers, consignors, consignees"] Accessed on: July 11, 2021. [Online]. Available: http://www.consultant.ru/document/cons_doc_LAW_71492/ 